\title{
Besi sığırı rasyonlarında tamamlayıcı yem olarak farklı şekillerde işlenmiş arpa ve mısır kullanımının performans, bazı biyokimyasal parametreler ile serum laktat ve bikarbonat düzeyi üzerine etkileri
}

\section{Effects of processed barley and corn supplementation on feedlot cattle diets on performance, some biochemical parameters and lactate and bicarbonate levels of blood}

\author{
Neşe Nuray TOPRAK ${ }^{1^{*}}$ iD, İsmail YAVAŞ ${ }^{1}$ iD Canberk BíLGEL $^{2}$ iD \\ ${ }^{1}$ Ankara Üniversitesi Ziraat Fakültesi Zootekni Bölümü Yemler ve Hayvan Besleme ABD, Dışkapı/Ankara \\ ${ }^{2}$ Büke Tarım ve Hayvancılık İthalat İhracat ve Ticaret Limited Şirketi, Elmadağ/Ankara
}

To cite this article:

Toprak, N.N, Yavaş, I., Bilgel, C., 2018. Besi sığırı rasyonlarında tamamlayıcı yem olarak farklı şekillerde işlenmiş arpa ve mısır kullanımının performans, bazı biyokimyasal parametreler ile serum laktat ve bikarbonat düzeyi üzerine etkileri. Harran Tarim ve Gida Bilimleri Dergisi, 22(2): 275-283

Address for Correspondence: Neşe Nuray TOPRAK e-mail:

nndede@agri.ankara.edu.tr

Received Date:

17.10.2017

Accepted Date:

17.04.2018

(C) Copyright 2018 by Harran University Faculty of Agriculture. Available on-line at www.dergipark.gov.tr/harranziraat cc) (1) 8 This work is licensed under a Creative Commercial 4.0 International Licen
Öz

Araştırma, besi sığırı rasyonlarına tamamlayıcı yem olarak ilave edilen arpa (öğütülmüş) ve farklı işlemlerden geçirilmiş mısırın (öğütülmüş, peletlenmiş ve flake) canlı ağırlık artışı, yem tüketimi, yemden yararlanma oranı, bazı biyokimyasal parametreler ile serum laktat ve bikarbonat seviyeleri üzerine etkilerinin belirlenmesi amacıyla yürütülmüştür. Araştırmada 13-14 aylık yaşta ve ortalama $324.9 \pm 1.36 \mathrm{~kg}$ canlı ağırlıkta, 20 adet Holştayn x Montofon melezi besi sığırı 4 gruba eşit olarak dağıtılmıştır. Deneme grupları, bazal rasyonlara metabolik enerji içeriği eşit olacak şekilde öğütülmüş arpa, öğütülmüş mısır, pelet mısır ve flake mısır ilave edilerek oluşturulmuştur. Araştırma sonunda performans verileri, kan parametreleri ve serum laktat ve bikarbonat düzeyleri bakımından gruplar arasında farklılık istatistiki olarak önemli bulunmamıştır ( $P>0.05)$. Ekonomik olması durumunda farklı işlemlerden geçirilmiş mısırın besi büyütme dönemi rasyonlarında tamamlayıcı yem olarak kullanılabileceği sonucuna varılmıştır.

Anahtar Kelimeler: Arpa, Besi, Flake mısır, Laktat

\section{ABSTRACT}

The aim of the research was to evaluate a possibility effect of supplementing barley (ground) and treated corn (ground, pelleted and flake) on the body weight gain, feed consumption, feed efficiency, and some blood biochemical parameters, serum lactate and bicarbonate levels of the beef catle. Twenty Holstein x Brown Swiss yearling beef bulls (324.9 $\pm 1.36 \mathrm{~kg}$ ) averaging 13-14 months of age were randomly assigned to four groups. The treatments were ground barley, ground corn, pelleted corn and steamflaked corn grain, respectively, substituting basal TMR according to the metabolisable energy content. At the end of the study, experimental treatments did not affect to performance, blood biochemical parameters, serum lactate and bicarbonate levels. It is concluded that proccessed corn could be used in fattening beef cattle in growth period if it is economical.

Key Words: Barley, Corn flake, Feedlot, Lactate 


\section{Giriş}

Besicilikte karlılık, sağlıklı hayvan, kaliteli ve ekonomik yem hammaddesi seçimi ve yemleme programlarının doğru yönetimi ile mümkündür. Beside maliyeti artıran en önemli unsur enerjisi yüksek yem hammadde teminidir. Ülkemizde arpa, yem sanayinin temel hammaddelerinden biri, besi yemlerinin vazgeçilmez enerji kaynağıdır. Her ne kadar enerji içeriği mısır ve buğdaydan düşük olsa da ham protein içeriğinin mısırdan daha yüksek ve buğdaya benzer olması, rumen sağlığı ve mikroorganizma popülasyonu (Nikkhah, 2011) ile et kalitesi üzerine olan olumlu etkileri sebebiyle arpa, besi rasyonlarında tercih edilmektedir. Arpa, besi döneminde yetiştiriciler tarafından çoğunlukla tek başına kullanılsa da fiyatı uygun olduğu zamanlarda mısır ve buğday ile ikame edilebilmektedir. Mısır, tüm çiftlik hayvanlarının beslenmesinde sorunsuz bir şekilde kullanılabilen yem hammaddesidir. Ancak yine de kullanımında dikkat edilmesi gereken hususlar bulunmaktadır. Ruminant yemlerinde mısır kullanımı etkileyen en önemli faktörler rumende parçalanabilir nişasta ve protein miktarı (Gibb ve McAllister, 2003) ile aşırı miktarda kullanımında et kalitesi üzerine olan olumsuz etkileridir.

Tahılların besin değerinin artırılmasında yem işleme tekniklerinden sıklıkla faydalanılmaktadır. Geçmişten günümüze partikül boyutunu küçülten öğütme ile başlayan, sonrasında ezme ile devam eden yem işleme tekniklerinin yanı sıra, teknolojinin gelişmesi ile ısıl işlem, buhar ve basınç uygulamalarının da kullanıldığı farklı teknikler geliştirilmiştir. Tahılların işlenmesi temelde metabolik enerjiden yararlanımın artırılması amacıyla yapılmaktadır. İşlemden geçirilmiş pek çok tahılın tüm dane şekline göre metabolik enerjisinin daha yüksek olduğu belirtilmektedir (Zinn ve ark., 2002). Bununla birlikte, işleme tekniklerinin yemlerde bulunan protein, nişasta ve selülozun sindirim oranı, yeri ve dağılımını da etkilediği bildirilmektedir (Mathison, 1996). Tahılların sindirilme dereceleri uygulanan işlem tekniği ve tahılın çeşidine göre değişiklik gösterebilmektedir. Yem işleme tekniklerinin sığırlarda arpanın sindirilebilirliğini artırdığı belirtilmektedir (Campling, 1991; Owens ve ark., 1997). Örneğin tüm dane arpa ile beslenen besi sığırlarında arpanın organik madde sindirilebilirliği ortalama \% 52.5 iken kuru ezme işleminden geçirilmiş arpa ile besleme de bu oran \% 85.2 olarak tespit edilmiştir (Toland, 1976). Benzer şekilde mısırın rumende sindirilebilirliğinin kırma ve ezme gibi yem işleme yöntemleri ile \% 5-10 oranında artırılabileceği belirtilmektedir (Lardy, 2013). Süt ineklerinde öğütülmüş mısır ile beslemenin kuru madde tüketimini azalttığı buna karşın yemden yararlanma oranını iyileştirdiği kaydedilmiştir (Yu ve ark., 1998). Zhang ve ark. (2010), süt emen buzağılarda yürüttükleri çalışmada flake mısır ve soya ağırlıklı buzağı başlatma yemi ile beslenen hayvanlarda yemden yararlanmanın iyileştiği, sütten kesimden sonra ishale yakalanma oranının azaldığı ve bazı kan parametrelerini değiştirdiğini tespit etmişlerdir.

Diğer taraftan, Nikkhah (2012) yemlere uygulanan işlemlerden beklenen etkinin ortaya çıkmasının optimum rumen koşullarında (örn. 5.8$6.0 \mathrm{pH}$ ) mümkün olabileceğini bildirmektedir. Düşük sıcaklık ve sürelerde yapılan yetersiz yem işleme uygulamaları, yem maliyetini artırdığı gibi işlenmiş yemlerden beklenen faydanın görülmemesine, aşırı işleme ise kuru madde tüketiminin azalması dolayısıyla hayvan performansının düşmesine neden olmaktadır (Hutjens ve Dann, 2000).

Yemlere uygulanan işlemlerin nişasta sindirimini iyileştirdiği ancak bunun rumende laktik asit üretim hızında artışa sebep olacağı, $\mathrm{pH}^{\prime} y ı$ düşüreceği ve buna bağlı olarak asidozis riski oluşturacağı belirtilmiştir (Owens ve ark., 1997). Yüksek tahıl içerikli rasyonlarla beslenen hayvanlarda kan laktat ve ruminal laktat seviyesi (Montano ve ark., 1999) arasında sıkı bir ilişki bulunmakta ve asidozis durumunda ruminal laktat seviyesi ile birlikte kan laktat seviyesinin de arttığı bildirilmektedir (Harmon ve ark., 1985). Bu sebeple besi sığırlarında 
rumen sağığının kontrol edilmesi amacıyla serum laktat düzeyinin tespiti yol gösterici olabilmektedir.

$\mathrm{Bu}$ araştırma ile arpa (öğütülmüş) ve farklı işlemlerden geçirilmiş (öğütülmüş, peletlenmiş ve flake) mısırın besi sığırlarında performans, bazı biyokimyasal parametreler ile serum laktat ve bikarbonat seviyesi üzerine etkilerinin belirlenmesi amaçlanmıştır.

\section{Materyal ve Metot}

Araştırmada hayvan materyali olarak 20 adet, ortalama kg canlı ağırlıkta 13-14 aylık yaşta Holştayn x Montofon melezi erkek sığırlar (316.7 \pm 11.22 kg CA) kullanılmıştır. Hayvanlar bağlı duraklı sistemde bireysel olarak beslenmiştir. Deneme, 10 günlük yeme alıştırma dönemi ile birlikte 75 gün sürdürülmüştür. Denemede kullanılacak tam rasyonlar (TMR) hazırlanmadan yem hammaddeleri ve konsantre besi büyütme yeminde besin maddesi analizleri AOAC (1995)'te bildirilen yöntemlerle yapılmış, bu değerlerden yararlanılarak metabolik enerji düzeyleri tespit edilmiştir (TSE, 1996). Deneme hayvanlarının rasyonları NRC (2000)'de bildirilen besin maddesi ihtiyaçlarına göre düzenlenmiştir. TMR'de kullanılan besi büyütme yeminin hazırlanmasında kullanılan hammaddeler, arpa, mısır, tritikale, pirinç kepeği, DDGS, kepek, ATK, soya yağı, melas, tuz, vitamin-mineral premiksi, toksin bağlayıcı ve mayadır. Yemlerin NDF ve ADF miktarları, ANKOM 2000 tam otomatik ham selüloz tayin cihazı ile Van Soest ve ark. (1991)'e göre belirlenmiştir. Araştırmada kullanılan yemlerin besin maddesi içerikleri Çizelge 1'de verilmiştir. Hayvanlara 1 ay boyunca; $2.25 \mathrm{~kg}$ saman, $1.75 \mathrm{~kg}$ kuru fiğ otu, 4.5 kg konsantre besi büyütme yemi, geri kalan 35 günlük dönemde ise, $2.0 \mathrm{~kg}$ saman, $2.1 \mathrm{~kg}$ kuru fiğ otu, $4.8 \mathrm{~kg}$ konsantre besi büyütme yeminden oluşan TMR eşit 2 öğün olacak şekilde yedirilmiştir. Tahıllar (arpa, mısır, pelet mısır, flake mısır) her birinden eşit oranda metabolik enerji gelecek şekilde hesaplanarak her 2 öğünde TMR üzerine ilave edilmiştir (Çizelge 2). Buna göre rasyonlara günlük ilave edilecek tahıl miktarları 1 . ve 2. dönemde sırasıyla, öğütülmüş arpa için 1.95 2.6 kg; öğütülmüş ve flake mısır için 1.82 - 2.43 kg; peletlenmiş mısır için ise $1,79-2.39 \mathrm{~kg}$ olarak bulunmuştur. Deneme süresince hayvanlar bireysel olarak beslenmiş, önlerinde sürekli içme suyu bulundurulmuştur.

Hayvanlar deneme başı, ortası ve sonu olmak üzere 3 kere sabah yemlemesinden 6 saat sonra tartılmış canlı ağırlıkları tespit edilmiştir. Buradan elde edilen verilerle besideki gün sayısı dikkate alınarak günlük canlı ağırlık artışları bulunmuş, yem tüketimleri ise haftalık olarak belirlenmiştir.

Deneme sonunda sabah yemlemesinden 2 saat sonra tüm hayvanların Vena coccygea damarından antikoagulantlı ve antikoagulantsız 2 ayrı kan tüpüne kan alınmıştır. Hayvanlardan alınan kanlar soğuk zincir koşullarında laboratuvara nakledilmiş, glikoz miktarının belirlenmesi için plazma, diğer parametrelerin tespiti için ise serum kısmı ayrılarak örnekler bekletilmeden analizler gerçekleştirilmiştir. Kan biyokimyasal analizleri ve laktat konsantrasyonu Roche-AU400 tam otomatik ölçüm cihazında, ticari kitler kullanılarak fotometrik olarak gerçekleştirilmiştir.

Denemeden elde edilen verilerin istatistiksel olarak değerlendirilmesinde Varyans Analizinden (SPSS 15.0), farklılıkların önem seviyelerinin tespit edilmesinde ise Duncan Çoklu Karşılaştırma Testi'nden yararlanılmıştır. 
Çizelge 1. Araştırmada kullanılan yemlerin besin maddeleri bileşimi (\%)

Table 1. The nutrient contents of experimental feeds (\%)

\begin{tabular}{|c|c|c|c|c|c|c|c|}
\hline \multicolumn{8}{|c|}{$\begin{array}{l}\text { Yemler } \\
\text { Feeds }\end{array}$} \\
\hline $\begin{array}{l}\text { Besin maddeleri } \\
\text { Nutrients }\end{array}$ & $\begin{array}{l}\text { Saman } \\
\text { Hay }\end{array}$ & $\begin{array}{l}\text { KFO } \\
\text { Vetch hay }\end{array}$ & $\begin{array}{c}\text { Besi Yemi } \\
\text { Concentrate } \\
\text { feed }\end{array}$ & $\begin{array}{l}\text { Ö. Arpa } \\
\text { G. Barley }\end{array}$ & $\begin{array}{l}\text { Flake Mısır } \\
\text { Corn flake }\end{array}$ & $\begin{array}{l}\text { Ö. Mısır } \\
\text { G.Corn }\end{array}$ & $\begin{array}{l}\text { Pelet Mısır } \\
\text { P.Corn }\end{array}$ \\
\hline $\begin{array}{l}\mathrm{KM} \\
\mathrm{DM}\end{array}$ & 93.22 & 90.78 & 90.68 & 90.87 & 89.84 & 89.14 & 90.67 \\
\hline $\begin{array}{l}\mathrm{HK} \\
\text { Ash }\end{array}$ & 6.57 & 9.87 & 7.27 & 3.60 & 0.90 & 2.60 & 1.94 \\
\hline $\begin{array}{l}\mathrm{HP} \\
\mathrm{CP}\end{array}$ & 2.74 & 12.10 & 13.67 & 10.65 & 7.11 & 8.98 & 9.82 \\
\hline $\begin{array}{l}\mathrm{HY} \\
E E\end{array}$ & 1.71 & 1.58 & 3.95 & 2.34 & 3.09 & 3.53 & 4.12 \\
\hline $\begin{array}{l}\left.\text { ME (kcal kg }{ }^{-1} \mathrm{KM}\right) \\
\mathrm{ME}\left(\mathrm{kcal}_{\mathrm{kg}} \mathrm{g}^{-1} \mathrm{DM}\right) \\
\text { NDF }\end{array}$ & 1206.8 & 1101.5 & 2922 & 3138.5 & 3394.9 & 3405.2 & 3419.0 \\
\hline $\begin{array}{l}\text { Neutral detergent } \\
\text { fiber }\end{array}$ & 73.72 & 57.82 & 25.53 & 26.98 & 8.87 & 12.70 & 12.18 \\
\hline $\begin{array}{l}\text { ADF } \\
\text { Acid detergent fiber }\end{array}$ & 51.99 & 47.52 & 12.40 & 11.96 & 3.79 & 4.19 & 5.00 \\
\hline
\end{tabular}

Çizelge 2. Denemede kullanılan TMR yapıları (\%)

Table 2. The composition of TMR (\%)

\begin{tabular}{|c|c|c|c|c|c|c|c|c|}
\hline & \multicolumn{8}{|c|}{$\begin{array}{l}\text { Muameleler } \\
\text { Groups }\end{array}$} \\
\hline & \multicolumn{4}{|c|}{$\begin{array}{l}\text { 1.Dönem (0-30. günler) } \\
1^{\text {st }} \text { Period }\left(0-30^{t h} \text { days) }\right.\end{array}$} & \multicolumn{4}{|c|}{$\begin{array}{l}\text { 2. Dönem (31-65. günler) } \\
2^{\text {nd }} \text { Period (31-65 }{ }^{\text {th }} \text { days) }\end{array}$} \\
\hline & $\begin{array}{c}\text { Ö. } \\
\text { Arpa } \\
\text { G.Barley }\end{array}$ & $\begin{array}{l}\text { Flake Misır } \\
\text { SFC }\end{array}$ & $\begin{array}{l}\text { Ö. Mısır } \\
\text { G.Corn }\end{array}$ & $\begin{array}{l}\text { Pelet Mısır } \\
\text { P.Corn }\end{array}$ & $\begin{array}{c}\text { Ö. } \\
\text { Arpa } \\
\text { G.Barley }\end{array}$ & $\begin{array}{c}\text { Flake Misır } \\
\text { SFC }\end{array}$ & $\begin{array}{c}\text { Ö. } \\
\text { Mısır } \\
\text { G.Corn }\end{array}$ & $\begin{array}{l}\text { Pelet Mısır } \\
\text { P.Corn }\end{array}$ \\
\hline $\begin{array}{l}\text { Yemler } \\
\text { Feeds }\end{array}$ & & & & & & & & \\
\hline $\begin{array}{l}\text { Saman } \\
\text { Straw }\end{array}$ & 20.95 & 22.19 & 22.19 & 22.26 & 16.54 & 17.79 & 17.79 & 17.86 \\
\hline $\begin{array}{l}\text { KFO } \\
\text { Vetch hay } \\
\text { Besi Yemi }\end{array}$ & 17.08 & 17.26 & 17.26 & 17.31 & 18.42 & 18.69 & 18.69 & 18.74 \\
\hline $\begin{array}{l}\text { Concentrate } \\
\text { feed }\end{array}$ & 43.90 & 44.38 & 44.38 & 44.51 & 42.11 & 42.70 & 42.70 & 42.86 \\
\hline $\begin{array}{l}\text { Ö. Arpa } \\
\text { G. barley } \\
\text { Flake Mısır }\end{array}$ & 18.07 & - & - & - & 22.93 & - & - & - \\
\hline $\begin{array}{l}\text { Steam flaked } \\
\text { corn }\end{array}$ & - & 16.17 & - & - & - & 20.82 & - & - \\
\hline $\begin{array}{l}\text { Ö. Mısır } \\
\text { G. corn }\end{array}$ & - & - & 16.17 & - & - & - & 20.82 & - \\
\hline $\begin{array}{l}\text { Pelet Mısır } \\
\text { Pelletted corn }\end{array}$ & - & - & - & 15.92 & - & - & - & 20.54 \\
\hline $\begin{array}{l}\text { Toplam } \\
\text { Total }\end{array}$ & 100.00 & 100.00 & 100.00 & 100.00 & 100.00 & 100.00 & 100.00 & 100.00 \\
\hline
\end{tabular}




\section{Araştırma Bulguları ve Tartışma}

Araştırmada besi sığırlarından elde edilen performans değerlerine ait ortalamalar Çizelge 3'te verilmiştir. Çalışmada, arpa ve farklı işlemlerden geçirilmiş mısır ile beslemenin, sığırlarda canlı ağırlık artışında (CAA) önemli bir farklılığa sebep olmadığı görülmüştür. Benzer bulgu, Loerch ve Fluharty (1998)'nin dane ve işlenmiş mısır ile beslenen sığırlarda yaptıkları araştırmada, Seoane ve ark. (1990) ile Beauchemin ve McGinn (2005) yaptıkları çalışmalarda da bulunmuş, arpa veya mısır ile beslenen düvelerde yem tüketimi ve CAA'nın değişmediği tespit edilmiştir. Diğer taraftan, Owens ve ark. (1997) tarafından hazırlanan çalışmada dane mısır, sorgum, buğday, darı ve arpa ile besinin CAA'yı değiştirmediğini, arpanın işlemden geçirilmesi durumunda benzer etkinin devam ettiğini ancak mısırın işlemden geçirilmesi ile CAA'nın arttığını bildirmişlerdir. Benzer şekilde bazı araştırıcılar, dane mısır yerine öğütülmüş veya kırılmış mısır ile beslemenin nişasta sindirimini artırdığı böylece canlı ağırlık artışının iyileştiği belirtmişlerdir (Galyean ve ark., 1979; Turgeon ve ark., 1983). Gorocica-Buenfil ve Loerch (2005) ise mısıra uygulanan öğütme işleminin sığırlarda performansı etkilemediğini kaydetmişlerdir. Li ve ark. (2011), rasyonlarda kırılmış mısır yerine belirli oranlarda ikame edilen flake mısır yedirilen sığırlarda performansı iyileştirdiği, günlük canlı ağırlık artışının kırılmış mısırda günlük $985.3 \mathrm{~g}$ iken flake mısırda $1351.4 \mathrm{~g}$ olarak bulunduğu kaydedilmiştir. Araştırma sonunda, yemden yararlanmanın \% 27.46 oranında iyileştiği, en iyi performansın flake mısırın, kırılmış mısırın \%90'ı yerine ikame edilmesi durumunda elde edildiği sonucuna varılmıştır. Corona ve ark. (2005), dane mısır, öğütülmüş mısır, flake mısır ve kuru ezme yöntemi ile işlenmiş mısır ile beslenen sığırlarda en yüksek CAA'nın flake mısır tüketen grupta gerçekleştiğini bildirmiştir. Benzer etki Gonzalez-Vizcarra ve ark. (2017) tarafından da kaydedilmiştir. Buzağı başlatma yemlerinde mısır ve arpanın birlikte kullanıldığı bir araştırmada, kuru ezme yöntemi ile işlenen tahılların öğütülmüş şekillerine göre büyüme üzerine daha etkili oldukları tespit edilmiştir (Rezapour ve ark., 2016). Besi büyütme ve bitirme rasyonlarında kullanılan flake mısırın büyüme performansını, hem ruminal hem de toplam sindirim kanalı içindeki nişasta sindirilebilirliğini artırmak suretiyle gerçekleştiği düşünülmektedir. Dane mısır ve pelet mısırın kuzularda besin maddesi sindirilebilirliği üzerine etkilerini belirlemek üzere yürütülen çalışmada (Hejazi ve ark., 1999), dane mısır tüketen gruplarda kuru madde, organik madde, NDF sindirilebilirliği ve azot kullanım etkinliği iyileşmiştir.

Mevcut çalışma sonuçlarına göre, hayvanların yem tüketimi ve yemden yararlanma oranları muamelelerden önemli seviyede etkilenmemiştir $(P>0.05)$ (Çizelge 3). Buna karşın, Tagawa ve ark. (2017) tahıllara uygulanan öğütme işleminin kuru madde tüketiminde artışa neden olduğunu bu sebeple öğütülmüş arpa ile beslenen besi sığırlarında ruminal asidosise yatkınlığın daha yüksek olduğunu belirtmişlerdir. Diğer taraftan Hale ve Theurer (1972), öğütülmüş tahıllarda tozlanma sebebiyle yem tüketiminin azalacağını bildirmişlerdir. Mevcut çalışmada öğütülmüş arpa ile beslenen hayvanlarda böyle bir sorunla karşılaşılmamıştır.

Farklı işlemlerden geçirilmiş tahıllarla beslenen ruminantlarda yapılan araştırmalar incelendiğinde, hayvanlarda canlı ağırlık artışı ve yem tüketimi bakımından birbirinden farklı sonuçlar elde edildiği görülmektedir. Araştırmamız ile literatür bildirişleri arasındaki farklılıkların rasyonlarda kullanılan kaba yem miktarları ile ilgili olduğu düşünülmektedir. Mevcut denemede rasyondaki kaba yem oranı \%3540 arasında tutulmuştur. Yapılan çalışmalarda ise genellikle yüksek yoğun yem içeren rasyonlar kullanılmıştır (\% 80-85 oranında). Rasyondaki kaba yem miktarı arttıkça rumen sağlığının iyileştiği ve metabolik bozukluklara yakalanma riskinin azaldığı ancak tahılların rumende kalış sürelerinin olumsuz etkilendiği ve rumeni daha çabuk terk ettikleri 
bildirilmiştir (Cole ve ark., 1976). Mevcut çalışmada yemlerden maksimum faydanın sağlanması için performans üzerine herhangi bir etkinin farklı yem hammaddeleri arasındaki negatif ve görülmemesinin başka bir sebebinin de yemlerin pozitif birliktelik etkisinin bilinmesi gerektiğini negatif birliktelik etkisi olduğu düşünülmektedir. belirtmiştir.

Sahlu ve ark. (2009) kaba yem ve konsantre

Çizelge 3. Farklı işlemlerden geçirilmiş mısır ve arpa ile beslemenin besi sığırlarında performans üzerine etkileri

Table 3. Effects of processed corn and barley on performance of feedlot cattle

\begin{tabular}{|c|c|c|c|c|c|c|}
\hline \multicolumn{7}{|c|}{$\begin{array}{c}\text { Muameleler } \\
\text { Groups }\end{array}$} \\
\hline Dönemler & Ö. Arpa & Flake Mısır & Ö. Mısır & Pelet Mısır & $\mathrm{P}$ & $\mathrm{OSH}$ \\
\hline Periods & G.Barley & Steam Flaked Corn & G.Corn & P.Corn & & SEM \\
\hline \multicolumn{7}{|c|}{ Canlı Ağırlık (kg) } \\
\hline \multicolumn{7}{|c|}{ Body weight (kg) } \\
\hline $\begin{array}{l}\text { Deneme Başı } \\
\text { Initial }\end{array}$ & 325.1 & 323.1 & 325.0 & 326.4 & 0.987 & 13.68 \\
\hline $\begin{array}{l}\text { Deneme Ortası } \\
\text { Second }\end{array}$ & 365.0 & 358.4 & 361.2 & 361.4 & 0.857 & 12.01 \\
\hline $\begin{array}{l}\text { Deneme Sonu } \\
\text { Finish }\end{array}$ & 430.4 & 408.4 & 423.0 & 423.7 & 0.499 & 22.52 \\
\hline \multicolumn{7}{|c|}{ Canlı Ağırlık Artışı (kg-1 gün) } \\
\hline \multicolumn{7}{|c|}{ Body weight gain ( $\left.\mathrm{kg}^{-1} \mathrm{day}\right)$} \\
\hline $\begin{array}{l}\text { 1.Dönem } \\
\text { First Period }\end{array}$ & 1.24 & 1.10 & 1.13 & 1.01 & 0.739 & 0.23 \\
\hline $\begin{array}{l}\text { 2.Dönem } \\
\text { Second Period }\end{array}$ & 1.42 & 1.09 & 1.34 & 1.38 & 0.406 & 0.31 \\
\hline $\begin{array}{l}\text { Ortalama } \\
\text { Mean }\end{array}$ & 1.35 & 1.10 & 1.26 & 1.36 & 0.435 & 0.23 \\
\hline \multicolumn{7}{|c|}{$\begin{array}{l}\text { Yem Tüketimi }\left(\mathrm{kg}^{-1} \text { gün) }\right. \\
\text { Feed intake }\left(\mathrm{kg}^{-1} \text { day) }\right.\end{array}$} \\
\hline $\begin{array}{l}\text { 1.Dönem } \\
\text { First period }\end{array}$ & 8.05 & 8.24 & 7.62 & 7.67 & 0.195 & 0.48 \\
\hline $\begin{array}{l}\text { 2.Dönem } \\
\text { Second period }\end{array}$ & 7.68 & 7.52 & 7.31 & 7.26 & 0.606 & 0.53 \\
\hline $\begin{array}{l}\text { Ortalama } \\
\text { Mean }\end{array}$ & 7.83 & 7.81 & 7.43 & 7.43 & 0.248 & 0.39 \\
\hline \multicolumn{7}{|c|}{ Yemden Yararlanma Oranı (kg YT ${ }^{-1}$ kg CAA) } \\
\hline \multicolumn{7}{|c|}{ Feed conversion ratio ( $\mathrm{kg} \mathrm{Fl}^{-1} \mathrm{~kg} B W G$ ) } \\
\hline $\begin{array}{l}\text { 1.Dönem } \\
\text { First period }\end{array}$ & 6.63 & 7.80 & 6.98 & 7.99 & 0.692 & 1.56 \\
\hline $\begin{array}{l}\text { 2.Dönem } \\
\text { Second period }\end{array}$ & 5.55 & 7.24 & 5.58 & 5.60 & 0.243 & 1.45 \\
\hline $\begin{array}{l}\text { Ortalama } \\
\text { Mean }\end{array}$ & 5.83 & 7.32 & 6.03 & 6.15 & 0.279 & 1.24 \\
\hline
\end{tabular}

Sorgum ve mısır ile yürütülen çalışmalarda, rasyonlarda kaba yem miktarının \% 20'nin üzerinde kullanılmasının sindirilebilirliği azalttığı dolayısıyla büyüme performansını olumsuz etkilediği (Bartle ve ark., 1994; Zinn ve ark., 1994) , diğer taraftan arpa ve buğday gibi çabuk fermente olabilir tahılları 
içeren rasyonlarda ise, belirli oranda kaba yem bulundurulmasının sindirim sistemi bozukluklarını önleyerek hayvanların performansını olumlu yönde etkilediği kaydedilmiştir (Kreikemeier ve ark., 1990).

Araştırmalarda kullanılan tahıl çeşidi, tahıl işleme tekniği ve uygulama süresi ile koşullarının da farklılıklara sebep olabileceği unutulmamalıdır. Örneğin, öğütülmüş tahıllarla yapılan çalışmalarda hayvan performansı bakımından görülen farklılıkların partikül boyutunun değişken olması ile ilgili olduğu belirtilmiştir (Gruyer, 1996; Engel ve ark., 2014). Tıpkı öğütme işleminde olduğu gibi flake elde edilmesinde de farklı ürünler ortaya çıkmakta, hatta flake inceliği dahi sonuçları etkileyebilmektedir (Zinn, 1990).

Araştırmada hayvanlardan alınan kanlarda yapılan analizlerden elde edilen ortalamalar Çizelge 4 ' te verilmiştir. Çalışmadan elde edilen sonuçlara göre, plazma glikoz, serum total protein, üre azotu ve trigliserid değerleri muamelelerden etkilenmemiştir $(P>0.05)$. Araştırmada gruplardan elde edilen ortalama serum bikarbonat değeri $25.64 \pm 0.36 \quad \mathrm{mmol} \mathrm{L}^{-1}$ bulunmuştur. Bu değer daha önce bildirilen 25.00 (Blood ve Studdet, 1993), 25.99 (Gökçe ve ark., 1998), $25.16 \mathrm{mmol} \mathrm{L}^{-1}$ (Karademir ve ark., 1999) değerleri ile uyumlu bulunmuştur.

Denemede serum laktat düzeyleri bakımından gruplar arasında bir fark görülmemiştir (Çizelge 4). Ancak Lesmeister (2003), peletlenmiş tahıl tüketen hayvanlarda nişasta sindirilebilirliğinin dolayısıyla laktik asit üretiminin de arttığını bildirmiştir. Benzer şekilde Castillo ve ark. (2006) da peletlenmiş yemlerin sığırlarda laktat seviyesini artırırken, bikarbonat seviyesini düşürdüğünü bulmuştur. Araştırmamızda, serum laktat ve bikarbonat seviyeleri incelendiğinde asidozis ile ilgili klinik bir bulguya rastlanmamıştır. Bunun rasyonda kullanılan kaba yem miktarı ve yeterli düzeyde mikrobiyal protein sentezi için gerekli olan ham proteinin yemlerle karşılanması ile ilgili olduğu düşünülmektedir.

Çizelge 4. Farklı işlemlerden geçirilmiş mısır ve arpa ile beslemenin besi sığırlarında kan biyokimyasal parametleri ile serum laktat ve bikarbonat seviyeleri üzerine etkileri

Table 4. Effects of processed corn and barley on biochemical parameters, serum lactate and bicarbonate level of feedlot cattle

\begin{tabular}{|c|c|c|c|c|c|c|}
\hline \multirow[b]{2}{*}{ Parametreler } & \multicolumn{4}{|c|}{$\begin{array}{c}\text { Muameleler } \\
\text { Groups }\end{array}$} & \multirow{3}{*}{$\mathrm{P}$} & \multirow{3}{*}{$\begin{array}{l}\text { OSH } \\
\text { SEM }\end{array}$} \\
\hline & Ö. Arpa & Flake Mısır & Ö. Mısır & Pelet Mısır & & \\
\hline Parameters & G.Barley & Steam Flaked Corn & G.Corn & P.Corn & & \\
\hline $\begin{array}{l}\text { Glukoz }\left(\mathrm{mg}^{-1} \mathrm{dL}\right) \\
\text { Glucose }\left(\mathrm{mg}^{-1} \mathrm{dL}\right)\end{array}$ & 47.40 & 73.00 & 50.80 & 76.80 & 0.197 & 24.91 \\
\hline $\begin{array}{l}\text { Toplam protein }\left(g^{-1} \mathrm{dL}\right) \\
\text { Total protein }\left(\mathrm{g}^{-1} \mathrm{dL}\right)\end{array}$ & 7.36 & 7.78 & 7.88 & 6.90 & 0.277 & 0.83 \\
\hline $\begin{array}{l}\text { Üre azotu }\left(\mathrm{mg}^{-1} \mathrm{dL}\right) \\
\text { Urea } \mathrm{N}\left(\mathrm{mg}^{-1} \mathrm{dL}\right)\end{array}$ & 21.4 & 31.6 & 30.4 & 20.0 & 0.156 & 9.28 \\
\hline $\begin{array}{l}\text { Trigliserit }\left(\mathrm{mg}^{-1} \mathrm{dL}\right) \\
\text { Triglyceride }\left(\mathrm{mg}^{-1} \mathrm{dL}\right)\end{array}$ & 20.4 & 22.8 & 33.2 & 27.0 & 0.393 & 12.04 \\
\hline $\begin{array}{l}\text { Laktat }\left(\mathrm{mmol}^{-1} \mathrm{~L}\right) \\
\text { Lactate }\left(\mathrm{mmol}^{-1} \mathrm{~L}\right)\end{array}$ & 1.19 & 1.14 & 1.09 & 1.15 & 0.989 & 0.46 \\
\hline $\begin{array}{l}\text { Bikarbonat }\left(\mathrm{mmol}^{-1} \mathrm{~L}\right) \\
\text { Bicarbonate }\left(\mathrm{mmol}^{-1} \mathrm{~L}\right)\end{array}$ & 26.26 & 24.80 & 26.24 & 25.24 & 0.723 & 2.44 \\
\hline
\end{tabular}




\section{Sonuç}

Tahıl işleme tekniklerinin besi hayvanları üzerindeki etkilerini inceleyen çalışmalarda pek çok faktörün sonuçları etkileyebildiği, bu yüzden net etkilerin ortaya konmasının oldukça güç olduğu görülmüştür. Bu faktörler, hayvanın ırkı, yaşı, besi süresi, işlemden geçirilecek tahıl çeşidi, varyetesi, uygulanacak işlem tekniği çeşidi, rasyonda kullanılan diğer yem hammaddeler, rasyonun ham protein ve NDF içeriği ile rasyon kaba yem oranı şeklinde özetlenebilir. Mevcut araştırma koşullarında besi sığırlarının rasyonlarında tamamlayıcı yem olarak kullanılan öğütülmüş arpa, öğütülmüş mısır, pelet mısır ve flake mısırın performans, bazı kan parametreleri ve serum laktat ve bikarbonat düzeyleri üzerine etkileri bakımından önemli seviyede bir farklılık bulunmamıştır.

\section{Ekler}

$\mathrm{Bu}$ araştırmaya katkılarından dolayı Büke Tarım ve Hayvancılık ithalat, ihracat ve Ticaret A.Ş’ye, teşekkür ederiz.

\section{Kaynaklar}

AOAC, 1995. Official methods of analysis. 16th ed. Association of Official Analytical Chemists; Arlington, VA.

Bartle, S.J., Preston, R.L., Miller, M.F., 1994. Dietary energy source and density: Effects of roughage source, roughage equivalent, tallow level, and steer type on feedlot performance and carcass characteristics. Journal of Animal Science, 72 :1943-1953.

Beauchemin, K.A., McGinn, S.M., 2005. Methane emissions from feedlot cattle fed barley or corn diets. Journal of Animal Science, 83: 653-661.

Blood, D.C., Studdert, V.P., 1993. Bailliere's Comprehensive Veterinary Dictionary. Bailliere Tindall, 1002, London.

Campling, R.C., 1991. Processing cereal grains for cattle-a review. Livestock Production Science, 28: 223-234.

Castillo, C., Hernandez, J., Mendez, J., Lena, J., Pereira, V., Lopez-Alonso, M., Benedito, J.L., 2006. Influence of grain processing on acid-base balance in feedlot steers. Veterinary Research Communications, 30: 823837.

Cole, N.A., Johnson, R.R., Owens, F.N., 1976. Influence of roughage level and corn processing method on the site and extent of digestion by beef steers. Journal of Animal Science, 43:490-496.
Corona, L., Rodriguez, S., Ware, R.A., Zinn, R.A., 2005. Comparative effects of whole, ground, dryrolled, and steam flaked corn on digestion and growth performance in feedlot cattle. The Professional Animal Scientist, 21(3):200-206.

Engel, C.L., Anderson, V.L., Schauer, C.S., 2014. Effects of corn particle size and forage level on performance and carcass traits of yearling steers during finishing. North Dakota Beef Report. https://www.ag.ndsu.edu/pubs/ansci/beef/AS173607.pdf. Erişim tarihi: Ağustos, 2016.

Galyean, M.L., Wagner, D.G., Owens, F.N., 1979. Corn particle size and site and extent of digestion by steers. Journal of Animal Science, 49:204-210.

Gibb, D.J., McAllister, T.A., 2003. Corn compared to barley in feedlot diets. $3^{\text {th }}$ Canadian Barley Symposium. http://redrockcorp.com.au/wpcontent/uploads/2014/09/Corn-compared-to-Barleyin-Feedlot-diets-1.pdf. Erişim tarihi: Ekim, 2016.

González-Vizcarra, V.M., Plascencia, A., Ramos-Aviña, D., Zinn, R.A., 2017. Influence of substituting steam-flaked corn for dry rolled corn on feedlot cattle growth performance when cattle are allowed either ad libitum or restricted access to the finishing diet. AsianAustralasian Journal of Animal Science, 30(11):15631567.

Gorocica-Buenfil, M.A., Loerch, S.C., 2005. Effect of cattle age, forage level, and corn processing on diet digestibility and feedlot performance. Journal of Animal Science, 83:705-714.

Gökçe, G., Paşa, S., Öcal, N., 1998. Some blood parameters, blood gases and urine analysis in Theileria infected cattle. Kafkas Universitesi Veteriner Fakültesi Dergisi, 4 (1-2): 43-47.

Gruyer, P.Q., 1996. Grain processing for feedlot cattle. Erişim adresi: http://www.ianrpubs.unl.edu/beef/g14.htm. Erişim tarihi: Kasım, 2016.

Hale, W.H., Theurer, C.B., 1972. Feed preparation and processing. D.C. Church (Ed.) Digestive physiology and nutrition of ruminants. Vol 3. Practical Nutrition. D.C. Church, Oregon Stage University, Corvallis, OR, pp. 4976.

Harmon, D.L., Britton, R.A., Prior, R.L., Stock, R.A., 1985. Net portal absorption of lactate and volatile fatty acids in steers experiencing glucose-induced acidosis or fed a $70 \%$ concentrate diet ad libitum. Journal of Animal Science, 60:560-569.

Hejazi, S., Fluharty, F.L., Perley, J.E., Loerch, S.C., Lowe, G.D., 1999. Effects of corn processing and dietary fiber source on feedlot performance, visceral organ weight, diet digestibility, and nitrogen metabolism in lambs. Journal of Animal Science, 77:507-515.

Hutjens, M.F., Dann, H.M., 2000. Grain processing: is it too coarse or too fine? http://www.livestocktrail.uiuc.edu/dairynet/paperDisp lay.cfm. Erişim tarihi: Kasım, 2016.

Karademir, B., Saatci, M., Çelebi, F., Erdoğan, H.M., Aksoy, A.R., 1999. Venous blood gaz values in cattle kept indoor. Kafkas Universitesi Veteriner Fakültesi Dergisi 5 
(2): 155-159.

Kreikemeier, K.K., Harmon, D.L., Brandt Jr,. R.T., Nagaraja, T.G., Cochran, R.C., 1990. Steam-rolled wheat diets for finishing cattle: Effects of dietary roughage and feed intake on finishing steer performance and ruminal metabolism. Journal of Animal Science, 68: 2130-2141.

Lardy, G., 2013. Feeding corn to beef cattle. https://www.ag.ndsu.edu/publications/livestock/feedi ng-corn-to-beef-cattle. Erişim tarihi: Ekim, 2016.

Lesmeister, K.E., 2003. Dietary alterations and their influence on rumen development in neonatal dairy calves, (PhD thesis, Pennsylvania State University).

Loerch, S.C., Fluharty, F.L., 1998. Effects of corn processing, dietary roughage level, and timing of roughage inclusion on performance of feedlot steers. Journal of Animal Science, 76:681-685.

Li, R., Cao, Y., Gao, Y., Li, Q., Li, J., 2011. Effects of steamflaked corn on the performance and blood biochemical parameters in finishing steers. Frontiers of Agriculture in China, 5(4): 588-593.

Mathison, G.W., 1996. Effects of processing on the utilization of grain by cattle. Animal Feed Science and Technology, 58: 113-125.

Montano, M.F., Chai, W., Zinn-Ware, T.E., Zinn, R.A., 1999. Influence of malic acid supplementation on ruminal $\mathrm{pH}$, lactic acid utilization, and digestive function in steers fed high-concentrate finishing diets. Journal of Animal Science, 77: 780-784.

National Research Council, 2000. Nutrient Requirements for Beef Cattle. 7th revised edition. National Academy of Sciences, Washington, DC.

Nikkhah A., 2011. Barley grain for rumen and ruminants: overmodernized uses of an inimitable fuel. In Barley: Production, Cultivation and Uses. Edited by Elfson SB. Nova Science Publishers, Inc, NY, USA. 247-258.

Nikkhah, A., 2012. Barley grain for ruminants: A global treasure or tragedy. Journal of Animal Science and Biotechnology, 3(1): 22-30.

Owens, F.N., Secrist, D.S., Hill, W.J, Gill, D.R., 1997. The effect of grain source and grain processing on performance of feedlot cattle: A review. Journal of Animal Science, 75:868-879.

Rezapour, M., Chashnidel, Y., Dirandeh, E., Shohreh, B., Ghaffari, A.H., 2016. The effect of grain processing and grain source on performance, rumen fermentation and selected blood metabolites of Holstein calves. Journal of Animal and Feed Sciences, 25: 203-209.

Sahlu, T., Dawson, L.J., Gipson, T.A., Hart, S.P., Merkel, R.C.,
Puchala, R., Wang, Z., Zeng, S., Goetsch, A.L., 2009. Impact of animal science research on U.S. goat production and predictions for the future. Journal of Animal Science, 87:400-418.

Seoane, J.R., Christen, A.M., Dion, S., 1990. Intake and digestibility in steers fed grass hay supplemented with corn or barley and fish meal or soybean meal. Canadian Journal of Animal Science, 70: 921-926.

Tagawa, S., Holtshausen, L., McAllister, T.A., Yang, W.Z., Beauchemin, K.A., 2017. Effects of particle size of processed barley grain, enzyme addition and microwave treatment on in vitro disappearance and gas production for feedlot cattle. Asian-Australasian Journal of Animal Science, 30(4): 479-485.

Toland, P.C., 1976. The digestibility of wheat, barley or oat grain fed either whole or rolled at restricted levels with hay to steers. Australian Journal of Experimental Agriculture and Animal Husbandry, 16:71-75.

TSE, 1996. Türk Standartları Enstitüsü. Hayvan yemleri metabolik enerjinin belirlenmesi (Kimyasal Metot). TSI No: 9610. Ankara, Turkey.

Turgeon, O.A., Brink Jr., D.R., Britton, R.A., 1983. Corn particle size mixtures, roughage level and starch utilization in finishing steer diets. Journal of Animal Science, 57:739749.

Van Soest, P.J., Robertson, J.B., Lewis, B.A., 1991. Methods for dietary fiber, neutral detergent fiber, and nonstarch polysaccharides in relation to animal nutrition. Journal of Dairy Science, 74(10): 3583-3597.

Yu, P., Huber, J.T., Santos, F.A., Simas, J.M., Theurer, C.B., 1998. Effects of ground, steam-flaked, and steamrolled corn grains on performance of lactating cows. Journal of Dairy Science, 81(3):777-783.

Zhang, Y.Q., He, D.Ch., Meng, Q.X., 2010. Effect of a mixture of steam-flaked corn and soybeans on health, growth, and selected blood metabolism of Holstein calves. Journal of Dairy Science, 93(5):2271-2279.

Zinn, R.A., 1990. Influence of flake density on the comparative feeding value of steam-flaked corn for feedlot cattle. Journal of Animal Science, 68:161-715.

Zinn, R.A., Plascencia, A., Barajas, R., 1994. Interaction of forage level and monensin in diets for feedlot cattle on growth performance and digestive function. Journal of Animal Science, 72: 2209-2215.

Zinn, R.A., Ownes, F.N., Ware, R.A., 2002. Flaking corn: Processing mechanics, quality standards, and impacts on energy availability and performance of feedlot cattle. Journal of Animal Science, 80:1145- 1156. 